\title{
Students' Attitudes and Perceptions towards Cultural Elements in Literary Texts
}

Faizah Mohamad, Nazatul Fatin Faizah Safarin Azuar, Zaemah Abdul Kadir, Nor Azah Mohd Rathi and Haniza Rais

To Link this Article: http://dx.doi.org/10.6007/IJARBSS/v11-i11/11691

DOI:10.6007/IJARBSS/v11-i11/11691

Received: 23 September 2021, Revised: 27 October 2021, Accepted: 10 November 2021

Published Online: 27 November 2021

In-Text Citation: (Mohamad et al., 2021)

To Cite this Article: Mohamad, F., Azuar, N. F. F. S., Kadir, Z. A., Rathi, N. A. M., \& Rais, H. (2021). Students' Attitudes and Perceptions towards Cultural Elements in Literary Texts. International Journal of Academic Research in Business and Social Sciences, 11(11), 2461-2470.

Copyright: (C) 2021 The Author(s)

Published by Human Resource Management Academic Research Society (www.hrmars.com)

This article is published under the Creative Commons Attribution (CC BY 4.0) license. Anyone may reproduce, distribute, translate and create derivative works of this article (for both commercial and non0-commercial purposes), subject to full attribution to the original publication and authors. The full terms of this license may be seen

at: http://creativecommons.org/licences/by/4.0/legalcode

Vol. 11, No. 11, 2021, Pg. $2461-2470$

Full Terms \& Conditions of access and use can be found at http://hrmars.com/index.php/pages/detail/publication-ethics 


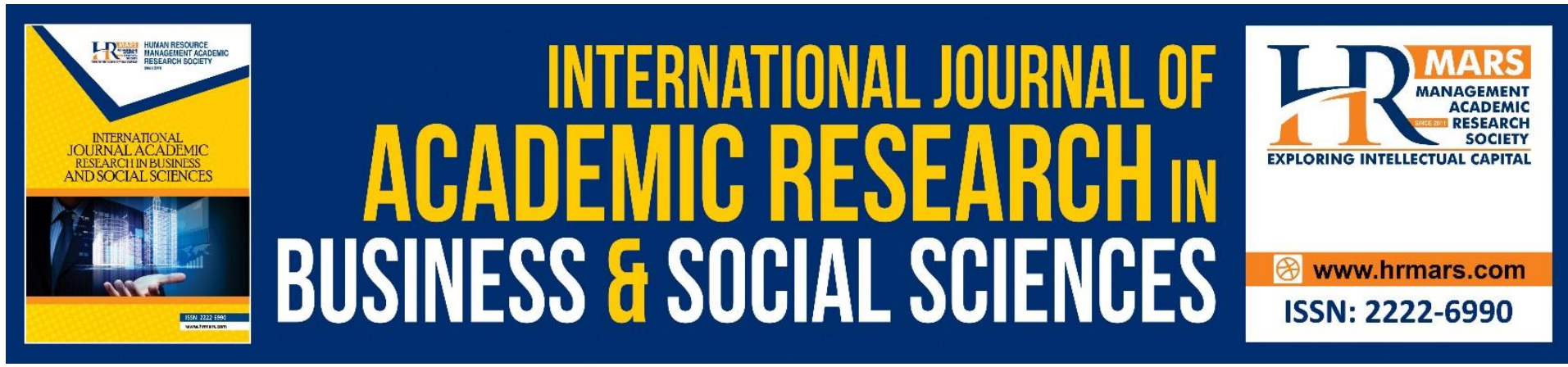

\title{
Students' Attitudes and Perceptions towards Cultural Elements In Literary Texts
}

\author{
Faizah Mohamad ${ }^{1}$, Nazatul Fatin Faizah Safarin Azuar ${ }^{2}$, \\ Zaemah Abdul Kadir ${ }^{3}$, Nor Azah Mohd Rathi ${ }^{4}$ and Haniza Rais ${ }^{5}$ \\ 1,2,3,4 Akademi Pengajian Bahasa, UiTM, Malaysia, ${ }^{5}$ Kulliyah of Education, IIUM, Malaysia \\ Email: 1fareema@uitm.edu.my, ${ }^{2}$ nazatulfatinfaizah@yahoo.com, ${ }^{3}$ zaemah@uitm.edu.my, \\ ${ }^{4}$ noraz0812uitm.edu.my, ${ }^{5}$ hanrais@iium.edu.my
}

\begin{abstract}
The study investigated the students' attitudes towards these culturally loaded literary texts and the extent these texts assist them in English language learning. A quantitative research method using a survey design was employed in the study. Using a random sampling technique, a set of questionnaires was distributed via Google Forms to students and 52 students responded to the questionnaire. The findings revealed that students had positive attitudes towards culturally loaded literary texts especially in a sense of respecting other people with different cultures. They also perceived that the cultural elements in literary texts helped them in improving their English language learning, especially in enriching their vocabulary. It was also discovered that there was a significant relationship between students' attitudes and perceptions on the role of cultural elements in literary text to improve their language learning. However, the students' education levels influenced neither the attitudes nor the perceptions. It is important to note that literary texts have the potential in enhancing students' linguistic competence and cultural competence, therefore, they should be integrated in the curriculum for other programmes and not only for English language programmes.
\end{abstract}

Keywords: Attitudes, Cultural Elements, English Language Learning, Literary Texts, Perceptions

\section{Introduction}

Literature has a unique set of discourses which consists of fiction and non-fiction texts. Besides, literature has become known as an increased strong and dynamic resource in language education as Malaysian education values literature for students. Many educators realise the importance of literary texts in English classroom as offering rich linguistic input, effective stimuli for students to express themselves, as well as potential sources of learners' motivation (Mahmud et al., 2019). Literary texts encourage students to enhance their interpretive skills by reflecting on what they really mean. When literary texts become powerful, they will be essential parts of the shared experience of a culture (Deane, 2020). 
According to Cheer and Menadue (2017), culture is the symbolic, ideational, and intangible aspects of the society. Since literature and culture share cultural properties such as values, behaviours, and language patterns (Belli, 2018), students will be able to make relations in literary texts from their cultural background. In addition, the cultural competence can be achieved through the language competence as literature can be used for basic language skills (Kaymakamoğlu \& Oktan, 2017).

Hill and Mustofa (2018) mentioned in their study that in order to comprehend a literary text from another culture, one needs to be able to make inferences and interpretations to obtain the text's insight and appreciate the literary work. There may be certain words written by the authors without giving any concepts or meanings for readers to understand directly. Readers have to broaden their knowledge of the author's culture. Thus, it is not enough to understand and appreciate a literary work just by reading everything in the literary texts without having the influence of readers' experience and cultural background to interpret the words and concepts in the text. Literary texts may narrow the cultural gap as the texts introduce the cultural aspects such as ideologies, values, traditions, and settings of both learners' own culture and also others (Mahmud et al., 2019).

\section{Literature Review}

Literature provides cultural knowledge and intercultural experience to the students whereby they can enhance both of their language proficiency, and cultural sensitivity towards the cultural problems (Tevdovska, 2016). The conflicts related to culture can be avoided as the students are taught about other people's history, customs, and traditions. Literary texts are essential because students will face the various types of cultural representations in the texts which help them to have a deeper understanding and gain more experience on other people's culture. Eventually, students can develop their intercultural competence, as well as awareness on cultural differences.

Culturally loaded literary texts could affect students' language skills as the degree of the awareness would be useful to develop linguistic skills. The level of cultural awareness and the broad knowledge of culture facilitate the learners' understanding in the reading materials such as literary texts. The reading materials that have a vast range of cultural contents such as customs, history, economy, and language are initially written by the native English users as their expression of the ideas in which represent the society and culture (Wang, 2018). According to Nasirahmadi et al (2014), literary texts which are loaded with other cultures' values, belief, customs and ideas will help students familiarize themselves with the cultural background knowledge as both cultural competence and linguistic competence are needed for the students to comprehend the text better. Kataja (2018) argued that literature is generally regarded as an effective learning strategy and is considered as very beneficial in language education because literary texts act as authentic materials for EFL learners. Not only that, but literature is also commonly utilized to increase the learners' English language skills as it offers the information or knowledge of the language use, and the culture of the language use.

There were several studies that investigated the students' attitudes or perceptions towards literary texts. For example, Tevdoska (2016) investigated the students' attitudes and the impact of their cultural background and experience in reading literary texts. She found that the respondents were receptive towards literary texts that included literary aspects that were different from their own culture. They thought that the literary texts were helpful if background information such as historical and social aspects as well as beliefs and values were 
provided in the texts. She further concluded that unknown and new cultural concepts could promote students' interest, interpretive stance and cultural awareness provided the background information related to the texts were pre-taught and explained to the students. Isariyawat et al (2020) also examined the students' attitudes towards literature, however, they added the elements of language skills in this study which was carried out among undergraduate students in Thailand. They discovered that the respondents felt that literary texts could help them develop the language skills; especially speaking, listening and reading skills, in which the students could sustain their discussions over a longer period and their perusing capacity had greatly improved when they read short stories or novels. They had also expanded their personal response and their knowledge about other cultures in their reflective composition which was written at the end of the semester.

Meanwhile, Kataja (2018) investigated the students' perceptions towards their experiences in literature and how the use of reading circles helps them in English language learning. She discovered that the students' experience in using literature vary widely and those who had lack of experience dealing with literary texts perceived reading and analysing literary texts in English classroom as challenging. Nevertheless, the students had positive perceptions towards reading circles in studying literature. Another study conducted by Mohammed Hasan and Fareeq Hasan (2019) examined the students' perceptions towards literature integration in English language learning. The findings of their study revealed that students were had positive perceptions towards their language development such as their vocabulary, speaking and reading skills as literary texts are loaded with words and expressions that are useful in helping students understand and be familiar with the English literary texts. The students also felt that literary texts gave them the opportunity to understand other cultures better by looking at the similarities and differences between cultures. In addition, literary texts had helped them developed a sense of personal, emotional, and intellectual growth. In a local context, Engku Atek et al. (2020) investigated the perceptions of Malaysian secondary school students towards the importance of the English literature component. They discovered that students perceived positively towards the English literature component to promote their cultural awareness, critical thinking skills and language aspects, for instance, grammar and vocabulary. Furthermore, the moral-philosophical approach was more favourable than the information-based and language-based approaches. This indicated that moral values gained from literary texts were appreciated by the students.

These studies have shown that literature and culture are interdependent, however, most of the studies were conducted abroad. Since studies on literature at the tertiary level in Malaysian settings are still relatively scarce, the present study aims to investigate the attitudes and perceptions of Malaysian university students towards cultural elements in literary texts. Therefore, there are four (4) research objectives of the study.

- To examine the attitudes of the students towards culturally loaded literary texts.

- To investigate the students' perceptions towards culturally loaded literary texts in assisting English language learning.

- To analyse the significant relationship between attitudes and perceptions of the students towards culturally loaded literary texts in assisting English language learning.

- To analyse the significant mean differences in students' attitudes and perceptions towards cultural elements in literary texts in assisting English language learning based on their education levels. 


\section{Methodology}

A quantitative research method using a survey design was employed in this study. The survey design is used in many quantitative studies because the data can be collected in a short period of time. It is also inexpensive, common and can be made accessible to a wider group of individuals (Gürbüz, 2017). A 23-item questionnaire was adapted from Tevdovska (2016), Belli (2018); Kataja (2018). The questionnaire consisted of three sections: Section A, Section $B$, and Section C. Section A gathered information on demographic data which were gender, age, and education levels. Section B covered the respondents' attitudes towards culturally loaded literary texts and Section C collected information on the perceptions towards cultural elements in literary texts on English language learning. The questionnaire was distributed randomly via a Google Form link to students enrolled in three different education levels: Diploma in TESL, Degree in TESL, and Master of Education in TESL. The researchers received 52 responses: 13 were from Diploma students, 25 were from Degree students and 14 were from Master students. The data gathered were then analysed using SPSS. The findings were reported in descriptive and inferential statistics. The significance level was set at 0.05 .

\section{Results and Discussion}

The findings of the study will be presented based on the research objectives of the study. The response type for the items was a 5-point Likert scale: (1) Strongly disagree; (2) Disagree; (3) Neither agree nor disagree; (4) Agree; (5) Strongly agree. According to Decker (2018), in a 5point Likert scale response, 3 is considered as the midpoint scale, therefore, any value resulting in more than 3 will be construed as overall approval and less than 3 point is disapproval.

Students' attitudes towards culturally loaded literary texts

Table 1: The attitudes towards culturally loaded literary texts

\begin{tabular}{llc}
\hline Item No & Attitudes & Mean \\
\hline$B 7$ & $\begin{array}{l}\text { I develop a sense of respect towards other people with } \\
\text { different cultures through literary texts. }\end{array}$ & 4.23 \\
\hline B5 & $\begin{array}{l}\text { I get to appreciate my cultural history, custom, and tradition } \\
\text { through literary texts. }\end{array}$ & 4.21 \\
\hline B8 & $\begin{array}{l}\text { It helps me when the text introduces cultural elements which } \\
\text { are familiar to me. }\end{array}$ & 4.17 \\
\hline B3 & $\begin{array}{l}\text { I like reading literary texts because there are many cultural } \\
\text { elements (beliefs, values, traditions). }\end{array}$ & 4.13 \\
\hline$B 9$ & $\begin{array}{l}\text { I am interested in getting to know more about the cultures } \\
\text { presented in the literary texts after reading them. }\end{array}$ & 4.07 \\
\hline B4 & $\begin{array}{l}\text { I like reading literary texts because it will vary my own language } \\
\text { use. }\end{array}$ & 4.03 \\
\hline B6 & $\begin{array}{l}\text { I accept literary texts which introduce topics and cultural } \\
\text { elements which differ from my own values and culture. }\end{array}$ & 3.96 \\
\hline$B 1$ & I enjoy reading or working with the literary texts. & 3.78 \\
\hline$B 10$ & $\begin{array}{l}\text { I recognize my cultural identity in the society through literary } \\
\text { texts. }\end{array}$ & 3.78 \\
\hline$B 2$ & I find it easy to work on the literary texts. & 3.44 \\
\hline
\end{tabular}


Table 1 showed that item B7, "I develop a sense of respect towards other people with different cultures through literary texts" had the highest mean at 4.23 on the attitudes towards culturally loaded literary texts. Then, it was followed by item B5, "I get to appreciate my cultural history, custom, and tradition through literary texts." with a mean of 4.21. Item B8 was next, "It helps me when the text introduces cultural elements which are familiar to me" at the mean of 4.17. Then, item B3, "I like reading literary texts because there are many cultural elements (beliefs, values, traditions)" had a mean at 4.13. Then, item B9, "I am interested in getting to know more about the cultures presented in the literary texts after reading them" with the mean of 4.07 . Next, item B4, "I like reading literary texts because it will vary my own language use" with a mean of 4.03 . This was followed by item B6, "I accept literary texts which introduce topics and cultural elements which differ from my own values and culture" which had a mean at 3.96. Item B1, "I enjoy reading or working with the literary texts" and item B10, "I recognize my cultural identity in the society through literary texts" had the same mean at 3.78). Finally, item B2, "I find it easy to work on the literary texts" had the lowest mean at 3.44 .

Based on the results, the students had positive attitudes towards culturally loaded texts as these texts could make them understand other people with different cultures better, be more accepting and appreciative of other cultures. The findings were supported by Belli (2018) and Tevdoska (2016) who also found that students were receptive towards cultural elements in literary texts. The incorporation of cultural elements in language instruction could avoid students from making inappropriate judgements on other cultures as they could identify the similarities and differences between their own and others' cultures.

The students' perceptions towards culturally loaded literary texts in assisting English language learning

Table 2: The students' perceptions towards culturally loaded literary texts in assisting English language learning

\begin{tabular}{|c|c|c|}
\hline Item No & Perceptions & Mean \\
\hline C4 & $\begin{array}{l}\text { I can learn language better when I am able to relate the topics and } \\
\text { themes of the literary texts to my cultural background. }\end{array}$ & 4.26 \\
\hline C1 & $\begin{array}{l}\text { Literary text is a good language learning resource to introduce } \\
\text { cultural elements. }\end{array}$ & 4.23 \\
\hline C6 & $\begin{array}{l}\text { My vocabulary will be enhanced by learning the cultural elements in } \\
\text { literary texts. }\end{array}$ & 4.09 \\
\hline $\mathrm{C7}$ & $\begin{array}{l}\text { My reading skills will be enhanced by learning the cultural elements } \\
\text { in literary texts. }\end{array}$ & 4.07 \\
\hline C9 & $\begin{array}{l}\text { I develop speaking skills in English for better interaction with people } \\
\text { from various cultures. }\end{array}$ & 4.07 \\
\hline C5 & $\begin{array}{l}\text { I prefer language activities that make me more aware of the cultural } \\
\text { settings in the literary texts. }\end{array}$ & 3.98 \\
\hline $\mathrm{C} 2$ & Target cultural elements should be included in language learning. & 3.94 \\
\hline $\mathrm{C} 8$ & $\begin{array}{l}\text { My writing skills will be enhanced by learning the cultural elements in } \\
\text { literary texts. }\end{array}$ & 3.92 \\
\hline C10 & $\begin{array}{l}\text { I am able to make connections between the cultural elements in the } \\
\text { literary texts with the language use around me. }\end{array}$ & 3.84 \\
\hline $\mathrm{C} 3$ & $\begin{array}{l}\text { I can learn language better by learning the cultural aspects in literary } \\
\text { texts. }\end{array}$ & 3.78 \\
\hline
\end{tabular}


Table 2 showed that item C4, "I can learn language better when I am able to relate the topics and themes of the literary texts to my cultural background" had the highest mean at 4.26. The second highest mean was item C1, "Literary text is a good language learning resource to introduce cultural elements" which was at 4.23. Next was item C6, "My vocabulary will be enhanced by learning the cultural elements in literary texts" with a mean of 4.09. Item C7, "I develop speaking skills in English for better interaction with people from various cultures" and item C9, "My reading skills will be enhanced by learning the cultural elements in literary texts" had the same mean of 4.07. Then, item C5, "I prefer language activities that make me more aware of the cultural settings in the literary texts" had a mean at 3.98. This was followed by item C2, "Target cultural elements should be included in language learning" with a mean of 3.94. After that, item $\mathrm{C} 8$, "My writing skills will be enhanced by learning the cultural elements in literary texts" had a mean at 3.92. The second last item was C10, "I am able to make connections between the cultural aspects in the literary texts with the language use around $m e$ " which had the mean at 3.84. Lastly, item C3, "I can learn language better by learning the cultural elements in literary texts" had the lowest mean at 3.78.

From the results, it can be seen that the students positively perceived that culturally loaded texts could help them in improving English language use and developing English language skills, especially vocabulary, reading and speaking. These findings were in line with several previous studies, for example, Nasirahmadi et al (2014) discovered that the students performed better in grammar, vocabulary and speaking fluency when they incorporated culturally loaded texts in their instruction. Meanwhile, Mohammed Hasan and Fareeq Hasan (2019) found that the students had positive perceptions towards their vocabulary, speaking and reading skills had improved when they were exposed to cultural words and expressions. In addition, Engku Etek et al. (2020) revealed that the students also perceived a positive development in their vocabulary and grammar using literature component. These showed that cultural elements in literary texts can reinforce English language learning.

4.3 The relationship between attitudes and perceptions of the students towards culturally loaded literary texts in assisting English language learning

Table 3: The relationship between attitudes towards literary texts and perceptions towards culturally loaded literary texts in assisting English language learning

\begin{tabular}{llcc}
\hline Variables & \multicolumn{1}{c}{ Statistic } & Attitudes & Perceptions \\
\hline Attitudes & Pearson & 1 & $.647^{* *}$ \\
& Correlation & & \\
& Sig. (2-tailed) & & .000 \\
& N & 52 & 52 \\
\hline Perceptions & Pearson & $.647^{* *}$ & 1 \\
& Correlation & & \\
& Sig. (2-tailed) & .000 & \\
& N & 52 & 52 \\
\hline
\end{tabular}

Table 3 showed that there was a positive correlation between attitudes towards literary texts and perceptions towards culturally loaded literary texts in assisting English language learning, $(r=.647, p<0.01)$. Hence, students who had positive attitudes towards literary texts would also have positive perceptions towards culturally loaded literary texts in assisting English language learning. This finding was corroborated by Mohammed Hasan and Fareeq Hasan (2019) who 
discovered that students had positive attitudes towards literature because literary texts not only developed their cultural competence, but also enhanced target language learning.

4.4 Students' attitudes and perceptions towards cultural elements in literary texts in assisting English language learning based on their education levels.

Table 4 below shows the descriptive statistics for the students' education levels, attitudes, and perceptions towards cultural elements in literary texts in assisting English language learning.

Table 4: Descriptive statistics for students' education levels, attitudes, and perceptions

\begin{tabular}{lclll}
\hline $\begin{array}{l}\text { Education } \\
\text { Levels }\end{array}$ & $N$ & Variables & Means & Std. Deviation \\
\hline Diploma & 13 & Attitudes & 4.0538 & .36882 \\
\cline { 3 - 5 } & & Perceptions & 3.9385 & .47177 \\
\hline Degree & 25 & Attitudes & 3.9160 & .47931 \\
\cline { 3 - 5 } & & Perceptions & 4.0000 & .40927 \\
\hline Master & 14 & Attitudes & 4.0429 & .47021 \\
\cline { 3 - 4 } & & Perceptions & 4.1429 & .51993 \\
\hline
\end{tabular}

In determining the differences in students' attitudes and perceptions towards cultural elements in literary texts based on the three students' education levels, one way ANOVA test was run.

Table 5: One way ANOVA test for attitudes and perceptions based on students' education levels

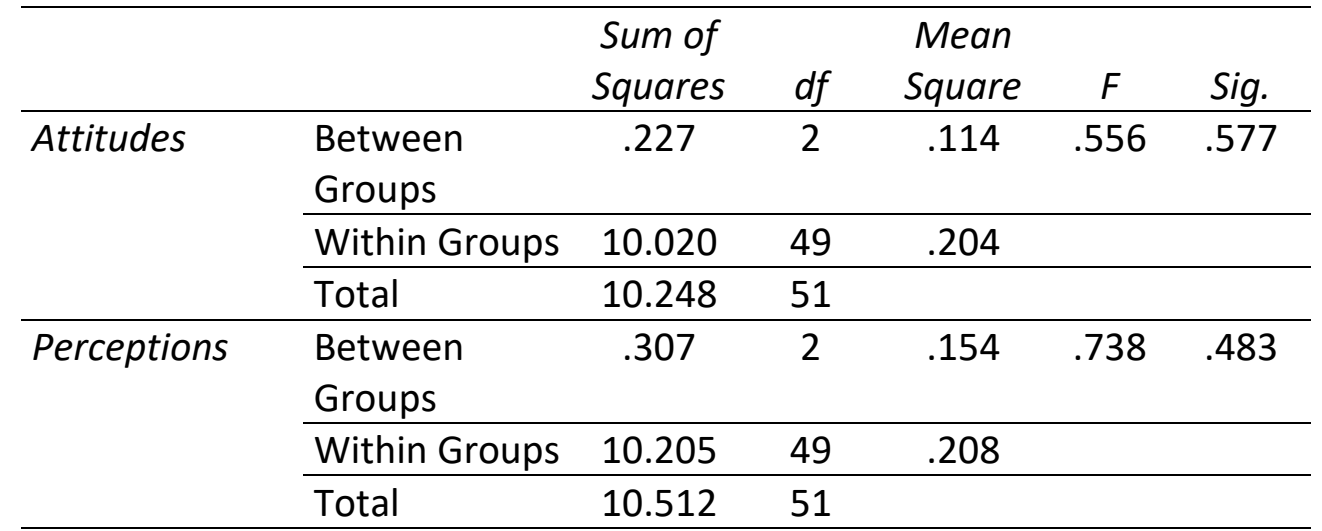

Table 5 showed that there were no significant mean differences in students' attitudes, $F(2,49)$ $=.556, p>0.05)$ and in students' perceptions, $F(2,49)=.738, p>0.05$, based on education levels. These indicated that students in all three education levels: Diploma, Degree, Master, had equal attitudes towards culturally loaded texts and had equal perceptions towards cultural elements in assisting English language learning. These findings were supported by Alfauzan and Hussain (2016) who found that students in two different language courses had the same attitudes and perceptions towards English literature. The insignificant differences in the students' attitudes and perceptions towards cultural elements in literary texts might be due to their similar background of study and the small number of the students participating in the present study. According to Singaram et al. (2008), among the factors that contribute to the insignificant results are the absence of group differences and small sample size. 


\section{Conclusion}

The discussion of the results has given sufficient empirical evidence in answering all four research questions. Based on the results, it can be concluded that students have positive attitudes towards cultural elements in the literary texts, which lead to their positive perceptions on the role of culturally loaded texts in enriching their English language learning, especially their vocabulary, reading skills and speaking skills. No significant mean differences in the students' attitudes and perceptions based on the students' education levels were found. This means that literary texts can possibly be introduced to students from various backgrounds so they can benefit from the texts for both linguistic and cultural purposes.

It is important to note that attitudes and perceptions of students are intricate and dynamic during their learning process, therefore, factors such as teaching materials, pedagogical approach, classroom settings, and other affective factors need to be taken into consideration when cultural elements in literary texts are incorporated in teaching and learning. Since students generally favour these cultural elements, teachers can optimise this enjoyment of learning experience by guiding and facilitating the students to develop the linguistic and cultural competence through these literary texts. Therefore, literary texts should be integrated not only in the curriculum for English programmes, but also for other programmes as well.

The present study has its limitation: it had a small sample size, it was a cross sectional study using a survey, it only included TESL students. Therefore, it is recommended that future research can have bigger sample size, employ a longitudinal study using both quantitative and qualitative research design, and involve other students from different programmes, but have an exposure to literature course. It is hoped that future research can give further insights on this area of study.

\section{References}

Belli, S. A. (2018). A study on ELT students' cultural awareness and attitudes towards incorporation of target culture into language instruction. Journal of Language and Linguistic Studies, 14(1), 102-124. https://www.researchgate.net/publication/328118452

Cheer, K. D., \& Menadue, C. B. (2017). Human Culture and Science Fiction: A Review of the Literature, 1980-2016. SAGE Open, 1-15. DOI: 10.1177/2158244017723690

Deane, P. (2020). Building and Justifying Interpretations of Texts: A Key Practice in the English Language Arts. ETS Research Report Series, (2), 1-53. DOI:10.1002/ets2.12304

Decker, F. (2018). How to average likert scale. https://sciencing.com/average-likert-scales6181662.html

Atek, E. S., Hassan, I., Latiff Azmi, M. N., Azmi, N. J., Yah Alias, M. H. (2020). Students' perceptions of the English literature component in Malaysian secondary schools. Language Related Research, 11 (5), 125-144. http://Irr.modares.ac.ir/article-14-45690en.html

Gürbüz, S. (2017). Survey as a quantitative research method.

https://www.researchgate.net/publication/321874371_Survey_as_a_Quantitative_Re search_Method

Hill, J. L., \& Mustofa, A. (2018). Understanding Cultural Context in Responding to Literature: Researching the Teaching of Literature in EFL Classroom Context. English Language Teaching, 11(6), 108-114. DOI: 10.5539/elt.v11n6p108 
Isariyawat, C., Yenphech, C., \& Intanoo, K. (2020). The role of literature and literary texts in an EFL context: cultural awareness and language skills. Journal of Language and Linguistic Studies, 16(3), 1320-1333. Doi: 10.17263/jlls.803748

Kataja, R. (2018). The use of literature in the EFL classroom: Students' perception. https://jyx.jyu.fi/bitstream/handle/123456789/57876/1/URN:NBN:fi:jyu201805072492.pdf

Kaymakamoğlu, S. E., \& Oktan, D. (2017). Using Literary Texts in EFL Classrooms: Cultural Awareness and Vocabulary Enrichment. International Journal of New Trends in Arts, Sports \& Science Education, 6(4), 70-85. http://www.ijtase.net/ojs/index.php/IJTASE/article/view/771

Mahmud, M. M., Ong, K., \& Ismail, O. (2019). Aligning the Teaching of English Literature in Malaysian Context: A Narrative Review. Asian Journal of Language, Literature and Culture Studies, 2(1), 1-10. DOI: 10.9734/AJL2C/2019/45029

Hasan, M. A., \& Hasan, F. Z. (2019). Students' perception towards literature integration in the English language departments at Duhok and Zakho universities. Advances in Language and Literary Studies, 10, 130-152. 10.7575/aiac.alls. v.10n.4p.130.

Nasirahmadi, A., Madarsara, F. A., \& Aghdam, H. R. (2014). Cultural issues and teaching literature for language learning. Procedia - Social and Behavioral Sciences, 98, 13251330. https://doi.org/10.1016/j.sbspro.2014.03.549

Singaram, V., Dolmans, D., Lachman, N., \& Van der Vleuten, C. (2008). Perceptions of problem-based learning (PBL) group effectiveness in a socially-culturally diverse medical student population. Education for Health Change in Learning \& Practice, 21(2):116

Tevdovska, E. S. (2016). Literature in ELT Setting: Students' Attitudes and Preferences towards Literary Texts. Procedia - Social and Behavioral Sciences, 232, 161-169. DOI: 10.1016/j.sbspro.2016.10.041

Wang, G. (2018). On the Strategies of Enhancing Students' Cultural Awareness in College English Teaching. English Language Teaching, 11(12), 116-120. DOI: 10.5539/elt.v11n12p116 